\title{
Dimethylsulfoniopropionate (DMSP) lyase activity in different strains of the symbiotic alga Symbiodinium microadriaticum
}

\author{
Denise M. Yost, Carys L. Mitchelmore* \\ University of Maryland Center for Environmental Science, Chesapeake Biological Laboratory, 1 Williams Street, \\ PO Box 38, Solomons, Maryland 20688, USA
}

\begin{abstract}
Dimethylsulfoniopropionate (DMSP) lyases are responsible for the enzymatic conversion of the algal metabolite DMSP into dimethylsulfide (DMS) and other products. DMSP lyase potential activity (DLA) was assayed in 5 cultured strains of Symbiodinium microadriaticum to investigate whether DLA was present and whether variations in DLA occurred among strains. S. microadriaticum are important primary producers symbiotic with corals and other cnidarians. Four of the 5 tested $S$. microadriaticum strains were capable of performing enzymatic lysis of DMSP, and the levels of DLA varied significantly among the strains. Average DLA normalized to chlorophyll a (chl a) was significantly higher in strain CCMP $829\left(5.3 \pm 0.9 \mathrm{nmol} \mathrm{DMS} \cdot \mathrm{min}^{-1} \cdot \mu^{-1}\right)$ compared with all other strains investigated. DLA was not detected in strain CCMP 830, suggesting that DMSP lyase may not be a universal enzyme in S. microadriaticum. DMSP levels also varied between strains, but there was no correlation between cellular DMSP and DLA. Additionally, our data indicate that in non-axenic $S$. microadriaticum strains, the bacterial contribution to DLA was not substantial in any of the algal cultures investigated. These results are supportive of the idea that $S$. microadriaticum contain DLA, that DMSP producers are not necessarily capable of DLA, and that, even within a species, DMSP and DLA levels vary significantly. These findings suggest important differences in the regulation of DMSP and DLA in $S$. microadriaticum, but the reasons for these differences remain to be elucidated.
\end{abstract}

KEY WORDS: Symbiodinium $\cdot$ DMSP lyase $\cdot$ Dimethylsulfoniopropionate $\cdot$ Coral

\section{INTRODUCTION}

Dimethylsulfoniopropionate (DMSP) is an algal metabolite that is produced by a wide variety of species at different intracellular concentrations (Keller et al. 1989). Marine dinoflagellates, including the coral symbiotic algae of the genus Symbiodinium, produce relatively high levels of DMSP (Keller \& Korjeff-Bellows 1996, Yoch 2002, Van Alstyne et al. 2006). DMSP and its enzymatic cleavage products have multiple proposed functions at the cellular level, including those of herbivory deterrent (Wolfe et al. 1997), algal osmolyte (Kirst 1996), antioxidant (Sunda et al. 2002), antiviral defense mechanism (Evans et al. 2006), overflow mechanism for excess reduced sulfur (Stefels
2000), methyl donor (Ishida 1968), sulfur storage compound (van Diggelen et al. 1986), foraging cue (DeBose et al. 2008) and cryoprotectant in polar algae (Kirst et al. 1991, Karsten et al. 1996). Dimethylsulfide (DMS) is a significant degradation product of DMSP, and is a major source of sulfur to the atmosphere (Kettle \& Andreae 2000). DMS is also reputed to affect ocean cloud cover and the radiative climate through formation of aerosols (Charlson et al. 1987).

The enzyme DMSP lyase (dimethylpropiothetin dethiomethylase, EC 4.4.1.3; DL) is responsible for DMSP conversion, producing DMS and other products (Johnston et al. 2008). This enzyme has been reported in phytoplankton (Steinke et al. 1998), macroalgae (Van Alstyne \& Houser 2003), bacteria (de Souza \& 
Yoch 1995) and fungi (Bacic et al. 1998). As demonstrated by Sunda et al. (2002), DMSP is reactive toward hydroxyl radicals $(\cdot \mathrm{OH})$, but its enzymatic cleavage products, acrylate and DMS, are $\sim 20$ and $\sim 60$ times more reactive towards $\cdot \mathrm{OH}$, respectively. Overall, the enzymatic conversion of DMSP forms several potential antioxidant scavengers (Sunda et al. 2002). Though many algal DMSP producers have DL capabilities (DMSP lyase potential activity [DLA]), this is not true for all algal species (Steinke et al. 1996, Niki et al. 2000, van Bergeijk \& Stal 2001, Sunda et al. 2002). Since DMSP and DLA potentially mitigate stress, investigations of how these parameters vary across Symbiodinium clades may improve understanding of the symbiont-host relationship.

Symbiodinium are the most prominent dinoflagellates in symbioses with marine invertebrates and protists and are commonly found with members of the phyla Cnidaria (i.e. corals, anemones), Platyhelminthes, Mollusca, Porifera and Foramnifera (Trench 1979, Pawlowski et al. 2001). Many symbiont host species have been shown to contain DMSP, including corals (Jones et al. 1994, Hill et al. 1995, Broadbent et al. 2002), anemones (Van Alstyne et al. 2006), flatworms (van Bergeijk \& Stal 2001) and clams (Jones et al. 1994, Hill et al. 2000, 2004). Evidence suggests that algal symbionts are responsible for DMSP production in cnidarian species due to a positive correlation between DMSP concentration and symbiotic algal densities (cell number) in cnidarian hosts, although partitioning between host corals and algal symbionts is unknown (Broadbent et al. 2002, Van Alstyne et al. 2006). Significant amounts of DMSP in reef corals suggest that these ecosystems could be significant sources of DMS to the atmosphere (Broadbent \& Jones 2004, Jones \& Trevena 2005), but it is currently unknown whether Symbiodinium have the enzymatic ability to convert DMSP into DMS. With evidence for DMSP variation in Symbiodinium from different coral species and bleached versus healthy corals (Hill et al. 1995, Broadbent et al. 2002, Van Alstyne et al. 2006, Jones et al. 2007), but no reports of DLA in Symbiodinium or their coral hosts, a characterization of baseline DMSP and DLA levels within and across algal and animal host species is warranted.

The present study investigated 5 Symbiodinium microadriaticum strains to determine (1) whether DLA was detectable in S. microadriaticum cultures, (2) whether DLA was primarily associated with the algal fraction of non-axenic cultures and (3) whether $S$. microadriaticum DLA and DMSP were significantly different between the algal strains investigated. Emiliania huxleyi strains were analyzed for comparison.

\section{MATERIALS AND METHODS}

Algal cultures. All experiments were conducted with strains of the dinoflagellate Symbiodinium microadriaticum and Emiliania huxleyi, purchased from the Provasoli-Guillard Center for the Culture of Marine Phytoplankton (CCMP; Bigelow Laboratory, Maine, USA). Algal strains included CCMP 373 and 374 (E. huxleyi; axenic) and S. microadriaticum CCMP 421, 828, 829, 830 and 1633 (Table 1). The cultures were maintained using sterile techniques and grown in sterile $\mathrm{K}, \mathrm{L} 1$ or $\mathrm{f} / 2$-Si media ( $\mathrm{pH}$ 8.0) according to preference (Bigelow Laboratory). S. microadriaticum cultures were not treated with antibiotics to obtain axenicity as our preliminary trials showed that antibiotic treatment negatively affected growth (data not shown). Thus, measures were taken to assess bacterial abundance and potential interference with DLA assays (detailed in 'Bacterial analyses' below). Algal cultures were grown at $26^{\circ} \mathrm{C}$ with a $12 \mathrm{~h}$ light: $12 \mathrm{~h}$ dark cycle, without agitation (Rogers \& Davis 2006). In common with other studies (Matrai \& Keller 1994), our preliminary trials demonstrated that DMSP levels were

Table 1. Symbiodinium microadriaticum and Emiliania huxleyi. CCMP algal strain characteristics and clade identification. All data (except for clade) from Provasoli-Guillard Center for the Culture of Marine Pytoplankton, Bigelow Laboratory, Maine, USA

\begin{tabular}{|c|c|c|c|c|c|}
\hline $\begin{array}{l}\text { CCMP } \\
\text { strain }\end{array}$ & Species & $\begin{array}{l}\text { Collection location } \\
\text { (very approximate) }\end{array}$ & Ocean & Isolated from & Clade \\
\hline 373 & E. huxleyi & Sargasso Sea & North Atlantic & Sea water & - \\
\hline 374 & E. huxleyi & Gulf of ME, USA & North Atlantic & Sea water & - \\
\hline 421 & S. microadriaticum & Wellington, NZ & South Pacific & Sea water & $\mathrm{E}$ \\
\hline 828 & S. microadriaticum & Florida Keys, FL, USA & North Atlantic & Sea water & $\mathrm{A}$ \\
\hline 829 & S. microadriaticum & $\begin{array}{l}\text { Great Barrier Reef, } \\
\text { Australia }\end{array}$ & South Pacific & $\begin{array}{c}\text { Tridacna crocea } \\
\text { (bivalve) }\end{array}$ & $\mathrm{A}$ \\
\hline 830 & S. microadriaticum & $\begin{array}{l}\text { Bermuda Biological } \\
\text { Station, Bermuda }\end{array}$ & North Atlantic & $\begin{array}{l}\text { Aiptasia pallida } \\
\text { (sea anemone) }\end{array}$ & $\mathrm{B}$ \\
\hline 1633 & S. microadriaticum & Hawaii, USA & North Pacific & $\begin{array}{l}\text { Aiptasia puchella } \\
\text { (sea anemone) }\end{array}$ & $\mathrm{B}$ \\
\hline
\end{tabular}


dependent upon the growth phase; therefore, all algal cultures were sampled during their exponential growth phase, at an average density of $1 \times 10^{5}$ cells $\mathrm{ml}^{-1}$. Each strain was grown in semi-continuous batch culture in $50 \mathrm{ml}$ conical flasks with $30 \mathrm{ml}$ of culture in each, under cool-white fluorescent bulbs $\left(100 \mu \mathrm{E} \mathrm{m} \mathrm{m}^{-2}\right.$ $\left.\mathrm{s}^{-1}\right)$. All cultures were sampled $2 \mathrm{~h}( \pm 1 \mathrm{~h})$ into their light periods as DMSP (and DLA) concentrations varied with diel cycle in $S$. microadriaticum (authors' pers. obs.) and have been reported to vary in other algal species as well (Bucciarelli et al. 2007, Jones et al. 2007, Stefels et al. 2007, Sunda et al. 2007). S. microadriaticum cultures were genetically verified for clade type (see 'Algal analyses'). Each of the strain replicates was grown separately and analyzed individually.

DMSP and DLA analyses. DMS analysis and calibration: All samples were analyzed with a HewlettPackard 5890 Series II gas chromatograph (GC) fitted with a Chromosil 330 packed column (Supelco) and a flame photometric detector (FPD). System temperature settings were $150^{\circ} \mathrm{C}$ for the injector, $60^{\circ} \mathrm{C}$ for the column oven and $175^{\circ} \mathrm{C}$ for the detector. Nitrogen gas was the carrier $\left(60 \mathrm{~cm}^{3} \mathrm{~min}^{-1}\right)$, and air $\left(60 \mathrm{~cm}^{3} \mathrm{~min}^{-1}\right)$ and hydrogen $\left(50 \mathrm{~cm}^{3} \mathrm{~min}^{-1}\right.$ ) were the flame gases. Data were collected and analyzed using HP ChemStation (Hewlett-Packard). Quantifications were made by headspace analysis following DMSP conversion to DMS by alkaline hydrolysis. Known concentrations of DMSP (purchased from Research Plus) were diluted in sterile water to give working solutions, which were frozen in small aliquots at $-80^{\circ} \mathrm{C}$. A standard curve for serial dilutions of DMSP was used to construct a calibration curve (using the square-root values of the peak area), and this linear regression served to convert peak areas from GC headspace measurements to DMS concentrations. Standards and controls ( $\mathrm{n}=5$ each) were prepared in parallel to experimental samples by using the same Tris buffer for DLA, incubating at $30^{\circ} \mathrm{C}$ for $20 \mathrm{~min}$ and using the same total liquid volume $(1 \mathrm{ml})$ in headspace vials. Addition of $5 \mathrm{~N} \mathrm{NaOH}$ to standards (final volume of $1 \mathrm{ml}$; final concentration of $5 \mathrm{~N} \mathrm{NaOH}$ ) occurred prior to heating, and all vials were placed in the dark for at least $4 \mathrm{~h}$ for equilibration prior to sampling. Analytical replicates were used only for interstrain assessment of repeatability. The precision of the DMS analysis was $<5 \%$, and headspace storage trials showed no DMS losses with the analytical methods employed. The detection limit of the GC was $1 \mathrm{nmol}$ $\mathrm{DMSP}^{-1}$.

Total and particulate DMSP analyses: Total DMSP was determined by placing $0.5 \mathrm{ml}$ of whole culture with $0.5 \mathrm{ml}$ of $10 \mathrm{~N} \mathrm{NaOH}$ into a headspace vial, sealing it and waiting at least $24 \mathrm{~h}$ for equilibration (equilibration times were optimized for all procedures; data not shown). Particulate DMSP (DMSP $)$ was deter- mined using a simple acidification/storage procedure ( $5 \mathrm{\mu l} 50 \% \mathrm{H}_{2} \mathrm{SO}_{4} \mathrm{ml}^{-1}$ of culture) followed by the total DMSP method (Kiene \& Slezak 2006). Appropriate controls $(n=5)$ were prepared in parallel to sample preparation.

DLA analyses: Our DLA methods were modified from procedures described by Harada et al. (2004) and Steinke et al. (2000) and optimized $(\mathrm{pH}$, exogenous DMSP concentration) for Symbiodinium microadriaticum. Briefly, DLA was determined by measuring the production rate of DMS prior to and after the addition of exogenous saturating levels of DMSP to permeabilized cells (using a Tris buffer, $200 \mathrm{mmol} \mathrm{l}^{-1}$ Tris containing $500 \mathrm{mmol} \mathrm{l}^{-1} \mathrm{NaCl}_{\text {; }} \mathrm{pH}$ 8). Algal cell permeabilization is necessary to allow exogenous DMSP into the cells in order to detect an enzymatic response to saturating DMSP levels. Tests showed that DLA increased in samples with Tris buffer compared to those without, and Tris buffer produced higher DLA than other means of cell disruption (homogenization, varied Tris buffer strength). We found that Tris buffer at $\mathrm{pH} 8$ yielded DLA in $S$. microadriaticum samples greater than those in $\mathrm{pH} 6$ Tris buffer. Appropriate controls (biotic and abiotic in parallel to sample preparation) and standards were run in tandem. Controls consisted of $0.5 \mathrm{ml}$ Tris buffer and $0.5 \mathrm{ml}$ culture medium amended with $5 \mu \mathrm{l}$ of $1 \mathrm{~mol} \mathrm{l}^{-1} \mathrm{DMSP}$ at $t_{0}$. Spot checks of Tris buffer and culture $\mathrm{pH}$ before and after DLA analysis were conducted and never deviated significantly from $\mathrm{pH} 8$ (stable at 7.98; $\mathrm{pH}$ above 8 results in increased abiotic conversion [any conversion of DMSP not attributed to biological enzymes]). Headspace vials were $6 \mathrm{ml}$ in volume and sealed with polytetrafluoroethylene (PTFE)/ rubber septa (National Scientific).

Algal cells in culture were concentrated by centrifugation at $1310 \times g$ for 5 min prior to placement in headspace vials. Concentrating the cells was necessary as the amount of DLA in some cultures was too small and needed to be adjusted according to the limitations of our analytical system (Steinke et al. 2000). Centrifugation has also been used previously for concentrating algal cells in DLA and DMSP/DMS experiments (Steinke et al. 1998, Broadbent et al. 2002). We did not use filters (e.g. GF/F) to capture cells because the filters could not be fully submerged in the small liquid volume of the headspace vials. After centrifugation, algal cells were resuspended in their native media to a final volume of $0.5 \mathrm{ml}$. Tris buffer was added to samples to permeabilize the cells. Preliminary trials in native media versus those in Tris buffer verified that the buffer was necessary for optimal DLA measurement. Tris buffer $(0.5 \mathrm{ml})$ was added to $0.5 \mathrm{ml}$ algal culture, sealed, incubated in a $30^{\circ} \mathrm{C}$ water bath for $20 \mathrm{~min}$ and vortexed vigorously for $3 \mathrm{~s}$ before sampling at each time point (at 
5 min intervals from 10 min prior to, through $30 \mathrm{~min}$ after, exogenous DMSP addition).

The temperature chosen for these experiments $\left(30^{\circ} \mathrm{C}\right)$ was previously recommended to enable comparisons among samples and studies (Steinke et al. 2000). At $t_{0 \text {, }}$ $5 \mu \mathrm{l}$ DMSP stock solution $\left(1 \mathrm{~mol} \mathrm{l}^{-1}\right)$ was added to give a final concentration of $5 \mathrm{mmol} \mathrm{l}^{-1}$. This amount of DMSP was found to be saturating for lyase-catalyzed DMS production in this system according to preliminary tests. At each time point, $50 \mu \mathrm{l}$ headspace samples were removed with an Agilent gas-tight syringe (same volume injected for all samples and standards) and injected into the GC for DMS measurement. At least 8 headspace samples (-10 min through $30 \mathrm{~min}$ ) were measured for each vial to yield a rate of DMS increase with time. DMS production was linear for all samples taken, and DLAs for all samples were corrected for abiotic conversion of DMSP by subtraction of DMS production rates measured in control vials. DLA is defined as nanomoles of DMS.per minute and is also reported as DLA:chl $a\left(\mathrm{nmol}\right.$ DMS $\left.\cdot \mathrm{min}^{-1} \cdot \mathrm{\mu g}^{-1}\right)$ and DLA:DMSP (nmol DMS $\left.\cdot \mathrm{min}^{-1} \cdot \mathrm{fmol}^{-1} \mathrm{DMSP}\right)$. On a per cell basis, DMSP is reported as femtomoles per cell.

Bacterial analyses. DLA in culture sample filtrates: Algal cultures were sub-sampled prior to centrifugation to determine bacterial contribution to overall DMS production. Culture samples were filtered using Isopore membrane filters (Millipore; $25 \mathrm{~mm}$ diameter, $2 \mu \mathrm{m}$ pore size) and gentle filtration (gravity or $<50 \mathrm{mmHg}$ vacuum; Steinke et al. 2000) to obtain an algal-free culture fraction while allowing unattached bacteria into the filtrate. Filtrate $(0.5 \mathrm{ml})$ was immediately placed in a $6 \mathrm{ml}$ headspace vial, $0.5 \mathrm{ml}$ of Tris buffer was added and DLA was assessed as described above. Filtrate samples without algae were scaled up to represent the amount of bacteria present in unfiltered (same volume of whole culture as the filtrate) samples to calculate the maximum bacterial DLA contribution to the reported algal DLA measurements. Specifically, the contribution to total potential DLA by bacteria (bacterial contribution) was calculated as follows for each replicate: (1) filtered bacterial counts were divided by unfiltered bacterial counts to determine the ratio of bacteria in the filtered versus unfiltered culture samples, and (2) filtered DLA quantities were divided by unfiltered DLA quantities at $t=30 \mathrm{~min}$; each DLA measure was corrected for abiotic conversion by subtracting the amount of DMS measured in controls. Bacterial contributions to total observed DLA (\%) were therefore calculated by dividing the above DLA ratio (Point 2) by the above bacterial count ratio (Point 1) and multiplying by 100 .

Bacteria enumeration: Prior to centrifugation, culture samples and culture filtrate sub-samples $(0.5 \mathrm{ml}$ each) were preserved (Sherr \& Sherr 1993), stained with 4'-6-diamidino-2-phenylindole (DAPI, final con- centration $20 \mu \mathrm{g} \mathrm{ml}^{-1}$ ) and filtered onto $0.8 \mu \mathrm{m}$ polycarbonate filters (after diluting for cell density) for bacterial enumeration. Cells were enumerated by counting 10 to 20 bacteria grid field ${ }^{-1}$ in 30 random fields filter ${ }^{-1}$ (1000-fold magnification) with an epifluorescence microscope (Kemp et al. 1993). Cell numbers in individual grids were averaged, and the numbers of cells per milliliter of culture was calculated.

Algal analyses. Symbiodinium microadriaticum were enumerated by hemocytometer using an epifluorescence microscope prior to and after centrifugation. Ten grid squares were counted for each sample and averaged to calculate the total number of algal cells per milliliter. Algal cell sizes were determined using a microscope, hemocytometer and eyepiece graticule. Chl a concentrations were measured fluorometrically with a Trilogy Laboratory Fluorometer (Turner Designs). Briefly, $1 \mathrm{ml}$ aliquots of unconcentrated culture were filtered through Whatman GF/F glass fiber filters and extracted in $90 \%$ acetone for $24 \mathrm{~h}$ at $4^{\circ} \mathrm{C}$ (Parsons et al. 1984). S. microadriaticum genetic diversity was assessed using standard RFLP methods to verify Symbiodinium clades (Table 1; Rowan \& Powers 1991). Algal DNA was extracted using the CTAB/phenol extraction methods as detailed by Coffroth et al. (1992) and Goulet \& Coffroth (1997) and was amplified with PCR using a 'universal' primer (ss5) and the zooxanthella-biased primer ss3Z (Rowan \& Powers 1991). Samples were subsequently digested with TaqI following the protocol of Goulet \& Coffroth (2004) and visualized by ultraviolet light after ethidium bromide staining of the product in a $2 \%$ agarose gel.

Statistical analyses. Prior to analyses, assumptions of normality and homogeneity were tested and data were transformed as necessary. Regression analyses were used to assess DLA among strains and the relationship between DMS concentration and cell number. Analysis of variance (ANOVA) was used to assess whether DLA:chl a measures differed among strains, filtrates, controls, or over time. ANOVA was also used to assess DMSP $_{\mathrm{p}}$ and total DMSP (particulate and dissolved; $\mathrm{DMSP}_{\mathrm{t}}$ ) values per cell. All statistical analyses were conducted using Minitab V. 10 (Minitab, Ver. 2000), with $\alpha=0.05$ for all tests.

\section{RESULTS}

\section{Algal DMSP}

For each of the Symbiodinium microadriaticum cultures investigated, $\mathrm{DMSP}_{\mathrm{t}}$ closely paralleled $\mathrm{DMSP}_{\mathrm{p}}$ measurements and were not significantly different ( $p>$ 0.05; Table 2). S. microadriaticum $\mathrm{DMSP}_{\mathrm{t}}$ per cell and DMSP $_{p}$ per cell varied according to strain with CCMP 


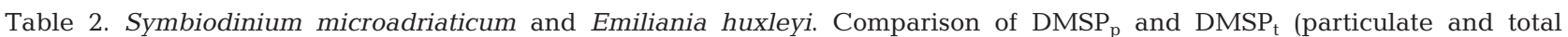
dimethylsulfoniopropionate; fmol cell ${ }^{-1}$ ) and DMSP lyase potential activity (DLA; $\mathrm{nmol} \mathrm{min}^{-1} \mathrm{fmol} \mathrm{DMSP}^{-1} ; \mathrm{nmol} \mathrm{min}^{-1} \mu \mathrm{g} \mathrm{chl} a^{-1}$ ) in cultured strains of E. huxleyi (CCMP 373 and 374) and S. microadriaticum (CCMP 421, 828, 829, 830 and 1633). Bacterial DLA in $S$. microadriaticum is also shown. Averages \pm SD are presented. Sample number is indicated in parentheses. ND: not detected; -: not tested

\begin{tabular}{|lccccc|}
\hline $\begin{array}{l}\text { CCMP } \\
\text { strain }\end{array}$ & $\begin{array}{c}\mathrm{DMSP}_{\mathrm{p}} \\
\left(\mathrm{fmol} \mathrm{cell}^{-1}\right)\end{array}$ & $\begin{array}{c}\mathrm{DMSP}_{\mathrm{t}} \\
\left(\mathrm{fmol} \mathrm{cell}^{-1}\right)\end{array}$ & $\begin{array}{c}\text { DLA:DMSP } \\
\left.\mathrm{nmol} \mathrm{min}^{-1} \mathrm{fmol} \mathrm{DMSP}^{-1}\right)\end{array}$ & $\begin{array}{c}\text { DLA:chl } a \\
\left(\mathrm{nmol} \mathrm{min}^{-1} \mu \mathrm{g}^{-1}\right)\end{array}$ & $\begin{array}{c}\text { Bacterial DLA } \\
(\% \text { of total DLA })\end{array}$ \\
\hline 373 & $7.6 \pm 2.3(5)$ & - & $0.1 \pm 0.01(5)$ & $0.2 \pm 0.1(4)$ & - \\
374 & $4.7 \pm 2.1(6)$ & - & $0.007 \pm 0.0002(2)$ & $0.006 \pm 0.005(2)$ & - \\
421 & $201.0 \pm 138.9(3)$ & $199.0 \pm 151.4(3)$ & $3.2 \pm 2.7(5)$ & $0.6 \pm 0.5(5)$ & $15.2 \pm 6.7(4)$ \\
828 & $122.6 \pm 60.7(3)$ & $105.5 \pm 51.6(4)$ & $4.7 \pm 1.6(4)$ & $0.8 \pm 0.3(4)$ & $1.4 \pm 0.8(3)$ \\
829 & $81.4 \pm 42.9(3)$ & $85.4 \pm 38.4(4)$ & $27.3 \pm 16.7(5)$ & $5.3 \pm 0.9(5)$ & $2.2 \pm 0.5(3)$ \\
830 & $33.8(1)$ & $43.0 \pm 14.5(4)$ & $\mathrm{ND}(4)$ & $\mathrm{ND}(4)$ & - \\
1633 & $329.9 \pm 193.2(3)$ & $347.9 \pm 201.9(4)$ & $6.5 \pm 2.7(4)$ & $0.7 \pm 0.4(4)$ & $1.0(1)$ \\
\hline
\end{tabular}

1633 having the greatest and CCMP 830 the least DMSP per cell. $\mathrm{DMSP}_{\mathrm{t}}$ and DMSP $_{p}$ per cell values for CCMP 1633 were significantly different from those for Emiliania huxleyi CCMP 373 and $374(\mathrm{p}<0.05)$, but not from those for other $S$. microadriaticum investigated. Average cell diameters $(\mu \mathrm{m})$ for $S$. microadriaticum strains were (average $\pm \mathrm{SD}_{;} \mathrm{n}=30$ strain $^{-1}$ ) as follows: CCMP 421 (10.28 \pm 1.08$), 828$ (10.69 \pm 1.11), $829(10.67 \pm 1.22), 830(10.74 \pm$ $1.12)$ and 1633 (9.72 \pm 0.82$)$; and for $E$. huxleyi strains were as follows: CCMP $373(5.08 \pm 0.63)$ and $374(5.03 \pm 0.66)$. Only CCMP 1633 was statistically different in cell size $(p<0.05)$ among the various $S$. microadriaticum strains. Both E. huxleyi cultures were found to have less DMSP $_{\mathrm{p}}$ when compared with $S$. microadriaticum cultures.

\section{Algal DLA}

In all strains, DMS evolution prior to exogenous DMSP addition (Fig. 1) was not statistically different from that in controls ( $p>0.05)$. DLA was greatest in strain CCMP 829 and was undetectable in CCMP 830. Additionally, when normalized to cell number or chl a (fmol cell ${ }^{-1}, \mathrm{nmol} \cdot \mathrm{min}^{-1} \cdot \mu \mathrm{g}^{-1}$ ), DLA for strains CCMP 373, 421, 828 and 1633 were markedly different from strain CCMP $829(\mathrm{p}<$ $0.01)$, but not from each other ( $p>0.05)$, and CCMP 374 was statistically different from all other strains $(\mathrm{p}<$ 0.01) (Fig. 2, Table 2). DLA:chl a for Emiliania huxleyi CCMP 373 was greater than that of CCMP 374, but
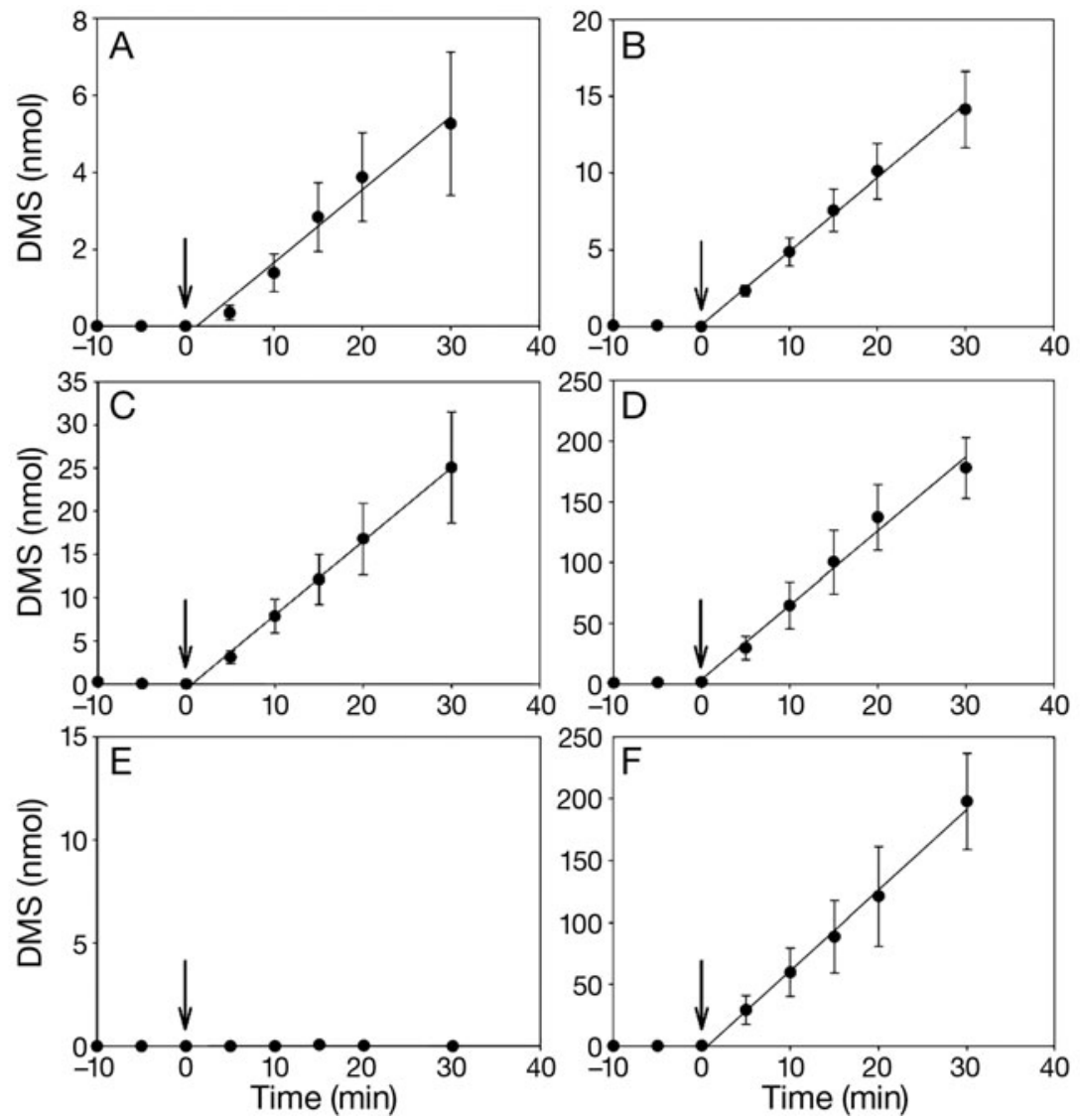

Fig. 1. Symbiodinium microadriaticum and Emiliania huxleyi. Dimethylsulfide (DMS; nmol) versus time (min) for (A) E. huxleyi strain CCMP 373, $\mathrm{n}=4$, and the following strains of $S$. microadriaticum: (B) CCMP 421, n = 5; (C) CCMP 828, $\mathrm{n}=4$; (D) CCMP 829, $\mathrm{n}=5$; (E) CCMP 830, $\mathrm{n}=4$; and (F) CCMP 1633, $\mathrm{n}=4$. Arrows indicate addition of dimethylsulfoniopropionate (DMSP) at $t_{0}$. Note different $y$-axis scales. Symbols indicate averages $\pm \mathrm{SE}$

less than all Symbiodinium microadriaticum investigated (except CCMP 830; Table 2). DLA:DMSP per cell averages were highest in strains 829 and $373(0.06$ and $0.02 \mathrm{nmol} \mathrm{DMS} \cdot \mathrm{min}^{-1} \cdot$ fmol $\mathrm{DMSP}^{-1}$, respectively) compared to other strains (Fig. 2). DLA:DMSP 


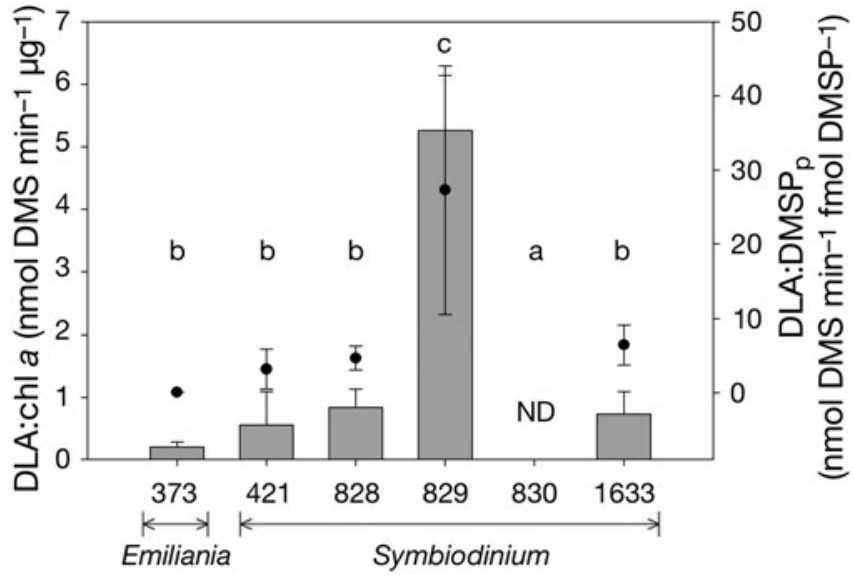

Fig. 2. Symbiodinium microadriaticum and Emiliania huxleyi. Dimethylsulfoniopropionate (DMSP) lyase activity (DLA):

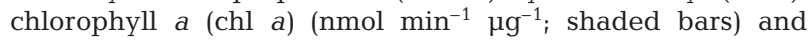
DLA:DMSP $_{\mathrm{p}}$ (particulate DMSP) (nmol DMS $\mathrm{min}^{-1} \mathrm{fmol}$ $\mathrm{DMSP}^{-1}$; $\bullet$ means for each strain. Error bars are $\mathrm{SD}_{\text {; }}$ different letters indicate significant differences (ANOVA, $p<0.01)$ and apply to both data sets; ND: not detected. DMS:chl a-CCMP 373, $\mathrm{n}=4$; CCMP 421, $\mathrm{n}=5$; CCMP 828, $\mathrm{n}=4$; CCMP 829, $\mathrm{n}=$ 5; CCMP 830, $\mathrm{n}=4$; and CCMP 1633, $\mathrm{n}=4$. Note: CCMP 374 is not depicted (see 'Results')

per cell for strain CCMP 829 was statistically higher than that for all other strains in Fig. 2 ( $p<0.01)$. CCMP 374 DLA measures $(n=2)$ are not presented in Fig. 2 because few replicates had measureable activity. Overall, CCMP 829 demonstrated the greatest DLA, whereas CCMP 421, 828 and 1633 had intermediate rates, with CCMP 830 having no detectable activity. Within strains, $\mathrm{DMSP}_{\mathrm{p}}$ concentrations were correlated with DLA. For each CCMP strain, $\mathrm{r}^{2}$ values (in parentheses) were as follows: $373(0.90), 374$ (0.86), 421 (0.87), 828 (0.66), 829 (0.53) and 1633 (0.72). However, $\mathrm{DMSP}_{\mathrm{p}}$ concentrations were not correlated with DLA between strains (those strains with high DMSP did not necessarily have high DLA).

\section{Bacterial contribution to DLA}

After correction for the quantity of bacteria in the whole culture versus that in the $2 \mu \mathrm{m}$ filtered sample, the calculated bacterial contribution to total DLA was found to be consistently low (Table 2). Bacterial DLA was greatest for strain CCMP 421 (approximately 15\% of the total) and averaged $<5 \%$ across all other strains (excluding CCMP 830 for which no DLA was detected). Therefore, the majority of DLA was associated with the algal component in all cultures examined. In bacterial filtrates, no algal contamination was detected in slide preparations using a fluorescence microscope. Furthermore, no algal cells were detected in the filtrate during bacterial enumeration (DAPI), whereas algal cells were observed in DAPI-stained whole culture samples. It was noted that algal cells in whole cultures did not appear to have attached bacteria as bacteria were evenly distributed and not concentrated around the dinoflagellate cells. Preliminary data (not shown) indicated minimal quantities of DMSP in the filtrate fractions of algal cell cultures examined for total DMSP. These data indicate a lack of algal contamination in filtrates.

\section{DISCUSSION}

Our results demonstrate that 4 of the 5 symbiotic dinoflagellate strains of the genus Symbiodinium examined in the present study are capable of performing the enzymatic lysis of DMSP to DMS, indicating DLA in these algae. S. microadriaticum strains demonstrated a range of DLA when grown in culture and exposed to exogenous DMSP addition. One of the $S$. microadriaticum strains in the present study (CCMP 830) did not demonstrate DLA, suggesting that DL is not a universal enzyme in this species or that DLA was not detected within our analytical capabilities. Furthermore, DLA was primarily associated with the algae (not bacteria) in the non-axenic cultures investigated.

Symbiodinium microadriaticum strains exhibiting DLA averaged DMS production rates of 0.6 to $5.3 \mathrm{nmol}$ $\cdot \min ^{-1} \cdot \mu \mathrm{g}^{-1} \mathrm{chl}$ a. The highest average DLA:chl a DLA in this study, $5.3 \mathrm{nmol} \cdot \mathrm{min}^{-1} \cdot \mu^{-1}$, occurred in CCMP 829. This strain was originally isolated from South Pacific clams, and DMSP concentrations in certain tissues of Tridacna sp. are some of the highest recorded in animal tissues to date (Hill et al. 2000). DLA for all algal lines closely parallel those reported by Harada et al. (2004) for particle-associated DLA in or near waters from the Gulf of Maine (DLA:chl $a=0.5$ to $7.9 \mathrm{nmol}$. $\min ^{-1} \cdot \mu \mathrm{g}^{-1}$ ). In their study, DLA:chl a rates ranged from $<5$ to $53 \mathrm{nmol} \cdot \mathrm{min}^{-1} \cdot \mu^{-1}$, with the highest rate (53) occurring at an oligotrophic sampling site in the Sargasso Sea dominated by prymnesiophytes and dinoflagellates. It appears that differences in DLA normalized to chl a may be due to several factors, including species composition. Other studies have shown a relationship between high DMSP:chl $a$ and DLA:chl $a$ and have attributed this, in part, to nutrient limitation (Sunda et al. 2007). It is not likely that nutrient limitation played a role in our experiments, though nutrient quantities were not specifically addressed. More detailed experiments addressing the role of nutrient limitation and enzyme kinetics in Symbiodinium are needed.

DLA differences were detected between the strains investigated, though we did not specifically address enzyme turnover rates. Our finding that DLA was not detectable in CCMP 830 is consistent with the observa- 
tions of Niki et al. (2000), who reported no DLA for 2 DMSP-producing Prymnesiophyceae species. The genus Symbiodinium encompasses 8 divergent clades (A to H) (for example, see Pochon et al. 2004, Coffroth \& Santos 2005), and it is generally accepted that these clades are composed of several lineages representing species complexes (Santos 2004). S. microadriaticum strains (CCMP 830 and 1633) are the same algal clade (i.e. Clade B), but were isolated from different host origins (Atlantic and Pacific Oceans, respectively) and have very different DLA potentials, suggesting intraclade DLA variation within a species (Table 2). Symbiodinium clades are known to have different susceptibilities to light and thermal stress (Rowan 2004), which may, in part, explain a corals' sensitivity to bleaching. We hypothesize that if DMSP has an antioxidant role in Symbiodinium, DMSP production and DLA in these algae might be expected to correlate with one of the primary mechanisms involved in coral bleaching, namely, damage to Photosystem II in the symbionts (Iglesias-Prieto et al. 1992, Lesser \& Farrell 2004). Susceptibility to Photosystem II damage may be mitigated if DMSP and its enzymatic cleavage products serve to alleviate conditions of oxidative stress by scavenging harmful reactive oxygen species (ROS; Sunda et al. 2002).

Because bacteria contributed $<5$ to $20 \%$ of the total DLA, the whole culture DLA values can be primarily attributed to the algal cells. Steinke et al. (2002a) reached a similar conclusion, finding that $>95 \%$ of DLA was found in the particle fraction $>2 \mu \mathrm{m}$. Bacterial DLA was greatest for CCMP 421, and this result is unexplained by the number of bacteria present in the filtrate. All cultures had similar ratios of bacteria to algae (approximately 5:1 on a per cell basis, respectively), and the amount of bacteria in the filtrate versus that in the total culture sample was also similar among strains $(76.9 \pm 16.6 \%)$. Bacterial DLA may in fact be overestimated due to algal cell rupture via filtration through polycarbonate filters, allowing algal contents into the experimental filtrate.

While the use of axenic cultures allows a more direct analysis of DLA in the algal component alone, we found that Symbiodinium microadriaticum treated with antibiotics had lower growth rates (data not shown). Additionally, checking cultures for axenicity by using standard plating techniques will miss a substantial portion of bacteria (Kogure et al. 1979). Though the bacteria in the present study were not genetically characterized, DLA could be over- or underestimated if a significant fraction of DMSP-utilizing bacteria (e.g. Roseobacter) were present in cultures. This is due to the finding that bacteria, in addition to the DL pathway, can also metabolize DMSP via the demethylation/demethiolation pathway, which would reduce the DMS quantities evolved (Taylor \& Gilchrist 1991). We do not suspect that demethylation/demethiolation played a substantial role in our experiments, as no methanethiol was detected. Alternatively, bacterial DLA may increase the quantity of DMS detected, an important factor that we have addressed in the present study and estimate to be small. It is also recognized that the possibility of algalattached bacteria cannot be excluded and may in fact be partially responsible for some of the observed DLA. However, during bacterial enumeration of whole culture samples, bacteria were not observed to be more numerous in close proximity to algal cells.

Our data demonstrate DLA variability within and across Symbiodinium microadriaticum strains, providing only the first step in an effort to further elucidate DLA regulation in the algae involved in numerous symbioses. DLA variability within strains could be attributed to several factors. According to Steinke et al. (2007) in their study of Emiliania huxleyi, in vivo DLA may vary during the course of a day due to enzyme turnover, and individual strains of algae may respond differently to exogenous substrate (DMSP) additions. Our finding that CCMP 373 has greater DLA than CCMP 374 is in agreement with other reports (Steinke et al. 1998), though differences in experimental conditions preclude direct comparison with previously reported rates (Steinke et al. 1998, 2000, 2007). Additionally, E. huxleyi DLAs in the present study were used to demonstrate the validity of the given assay for the detection and optimization of DLA in S. microadriaticum; the assay was not optimized for E. huxleyi DLA measurements. While several assay parameters differed when compared to those in previous studies, our E. huxleyi data are in agreement with published DLA measurements when calculations incorporate differences in activity associated with $\mathrm{pH}$. For example, using data presented by Steinke et al. (1998), the calculated DLA:DMSP $\left(\mathrm{nmol}\right.$ DMS $\left.\cdot \mathrm{min}^{-1} \cdot \mathrm{fmol}^{-1} \mathrm{DMSP}\right)$ for CCMP 373 is 0.27 at an optimal $\mathrm{pH}$ of 6 , but, at $\mathrm{pH}$ 8 , it would be approximately $10 \%$ of that value based on the reported pH trials. Additional sources of variability may include shifts in enzyme affinity during growth, culture conditions and individual variability associated with enzyme assay parameters. Given these observations, the present study demonstrates that some $S$. microadriaticum have DL capabilities and that DLAs are distinguishable between algal strains at the given concentration of exogenous DMSP addition.

Symbiodinium are known to contain substantial quantities of DMSP (Jones et al. 1994, Hill et al. 1995, Broadbent et al. 2002, Broadbent \& Jones 2004), with cultured zooxanthellae having $179 \mathrm{fmol} \mathrm{cell}^{-1}$ DMSP (Keller et al. 1989). Our DMSP measurements for $S$. microadriaticum strains (34 to $330 \mathrm{fmol} \mathrm{cell}^{-1}$ ) are in 
agreement with those from previous studies (Jones et al. 1994, Hill et al. 1995, Broadbent et al. 2002). Several studies support the hypothesis that DMSP and DLA are produced at varying levels by different organisms and that DMSP and DLA vary between strains of the same species (Steinke \& Kirst 1996, Steinke et al. 1996, 2002a,b, Wolfe et al. 1997, Niki et al. 2000). Our comparisons of per cell DMSP between the 5 strains of $S$. microadriaticum tested revealed differences, so further investigations of DMSP levels within Symbiodinium are warranted. We found no apparent correlation between intracellular DMSP concentrations and DLA between strains, though strain CCMP 830 had no detectable DLA and also had the lowest DMSP concentrations of the $S$. microadriaticum strains investigated.

Corals (host and algal cells) may be exposed to conditions of elevated oxidative stress when harmful ROS are not scavenged or detoxified by antioxidants. Because corals contain photosynthetic, oxygenproducing algae, high levels of antioxidant enzymes (and free radical scavengers) are found in host (and algal) tissues (Lesser \& Shick 1989, Dykens et al. 1992, Downs et al. 2002). With proposed antioxidant functions, DMSP, and more importantly its enzymatic cleavage products via DLA, may play significant roles in alleviating conditions of oxidative stress on reefs. To investigate this potential antioxidant role we are exploring the effects of various oxidative stressors on DMSP levels and DLA in isolated Symbiodinium microadriaticum. Our studies herein have shown that coral symbiotic algae contain DLA, and further studies are directed towards determining if cnidarian hosts, in common with other symbiotic host species, contain DLA.

Acknowledgements. We thank all of those at the Chesapeake Biological Laboratory who have graciously supported this work. We are grateful to W. G. Sunda, whose suggestions helped improve the manuscript. Thanks also to C. Rowe, M. A. Coffroth, J. Baker, B. Crimmins and S. Perez. The manuscript was improved by constructive comments from 3 anonymous reviewers. This is Contribution No. 4267 of the University of Maryland Center for Environmental Science.

\section{LITERATURE CITED}

Bacic MK, Newell SY, Yoch DC (1998) Release of dimethylsulfide from dimethylsulfoniopropionate by plant-associated salt marsh fungi. Appl Environ Microbiol 64:1484-1489

Broadbent AD, Jones GB (2004) DMS and DMSP in mucus ropes, coral mucus, surface films and sediment pore waters from coral reefs in the Great Barrier Reef. Mar Freshw Res 55:849-855

Broadbent AD, Jones GB, Jones RJ (2002) DMSP in corals and benthic algae from the Great Barrier Reef. Estuar Coast Shelf Sci 55:547-555

Bucciarelli E, Sunda WG, Belviso S, Sarthou G (2007) Effect of the diel cycle on production of dimethylsulfoniopropionate in batch cultures of Emiliania huxleyi. Aquat Microb Ecol 48:73-81

Charlson RJ, Lovelock JE, Andreae MO, Warren SG (1987) Oceanic phytoplankton, atmospheric sulphur, cloud albedo and climate. Nature 326:655-661

Coffroth MA, Santos SR (2005) Genetic diversity of symbiotic dinoflagellates in the genus Symbiodinium. Protist 156: 19-34

Coffroth MA, Lasker HR, Diamond ME, Bruenn JA, Bermingham E (1992) DNA fingerprints of a gorgonian coral: a method for detecting clonal structure in a vegetative species. Mar Biol 114:317-325

de Souza MP, Yoch DC (1995) Comparative physiology of dimethyl sulfide production by dimethylsulfoniopropionate lyase in Pseudomonas doudoroffii and Alcaligenes sp. strain M3A. Appl Environ Microbiol 61:3986-3991

DeBose JL, Lema SC, Nevitt GA (2008) Dimethylsulfoniopropionate as a foraging cue for reef fishes. Science 319:1356

Downs CA, Fauth JE, Halas JC, Dustan P, Bemiss J, Woodley CM (2002) Oxidative stress and seasonal coral bleaching. Free Radic Biol Med 33:533-543

Dykens J, Shick J, Benoit C, Buettner G, Winston G (1992) Oxygen radical production in the sea anemone Anthopleura elegantissima: and its symbiotic algae. J Exp Biol 168:219-241

Evans C, Malin G, Wilson WH, Liss PS (2006) Infectious titers of Emiliania huxleyi virus 86 are reduced by exposure to millimolar dimethyl sulfide and acrylic acid. Limnol Oceanogr 51:2468-2471

Goulet TL, Coffroth MA (1997) A within colony comparison of zooxanthellae genotypes in the Caribbean gorgonian Plexaura kuna. In: Lessios HA, MacIntyre IG (eds) Proc 8th Int Coral Reef Symp, Vol 2. Smithsonian Tropical Research Institute, Balboa

Goulet TL, Coffroth MA (2004) The genetic identity of dinoflagellate symbionts in Caribbean octocorals. Coral Reefs 23:465-472

> Harada H, Rouse MA, Sunda W, Kiene RP (2004) Latitudinal and vertical distributions of particle-associated dimethylsulfoniopropionate (DMSP) lyase activity in the western North Atlantic Ocean. Can J Fish Aquat Sci 61: $700-711$

Hill RW, Dacey JWH, Krupp DA (1995) Dimethylsulfoniopropionate in reef corals. Bull Mar Sci 57:489-494

Hill RW, Dacey JWH, Edward A (2000) Dimethylsulfoniopropionate in giant clams (Tridacnidae). Biol Bull 199: 108-115

> Hill RW, Dacey JWH, Hill SD, Edward A, Hicks WA (2004) Dimethylsulfoniopropionate in six species of giant clams and the evolution of dimethylsulfide after death. Can J Fish Aquat Sci 61:758-764

> Iglesias-Prieto R, Matta WA, Robins WA, Trench RK (1992) Photosynthetic response to elevated temperature in the symbiotic dinoflagellate Symbiodinium microadriaticum in culture. Proc Natl Acad Sci USA 89:10302-10305

Ishida Y (1968) Physiological studies on evolution of dimethylsulfide from unicellular marine algae. Mem College Agricult Kyoto Univ 94:47-82

Johnston AWB, Todd JD, Sun L, Nikolaidou-Katsaridou MN, Curson ARJ, Rogers R (2008) Molecular diversity of bacterial production of the climate-changing gas, dimethyl sulphide, a molecule that impinges on local and global symbioses. J Exp Bot 59:1059-1067

> Jones GB, Trevena AJ (2005) The influence of coral reefs on atmospheric dimethylsulphide over the Great Barrier Reef, Coral Sea, Gulf of Papua and Solomon and Bismarck Seas. Mar Freshw Res 56:85-93 
Jones GB, Curran MAJ, Broadbent AD (1994) Dimethylsulphide in the South Pacific. In: Bellwood O, Choat H, Saxena N (eds) Recent advances in marine science and technology. Pacon International and James Cook University Press, Townsville, p 183-190

Jones G, Curran M, Broadbent A, King S, Fischer E, Jones R (2007) Factors affecting the cycling of dimethylsulfide and dimethylsulfoniopropionate in coral reef waters of the Great Barrier Reef. Environ Chem 4:310-322

Karsten U, Kück K, Vogt C, Kirst GO (1996) Dimethylsulfoniopropionate production in phototrophic organisms and its physiological function as a cryoprotectant. In: Kiene RP, Visscher PT, Keller MD, Kirst GO (eds) Biological and environmental chemistry of DMSP and related sulfonium compounds. Plenum Press, New York, p 143-153

Keller MD, Korjeff-Bellows W (1996) Physiological aspects of the production of dimethylsulfoniopropionate. In: Kiene RP, Visscher PT, Keller MD, Kirst GO (eds) Biological and environmental chemistry of DMSP and related sulfonium compounds. Plenum Press, New York, p 131-142

Keller MD, Bellows WK, Guillard RRL (1989) Dimethyl sulfide production in marine phytoplankton. In: Saltzman ES, Cooper WJ (eds) Biogenic sulfur in the environment. American Chemical Society, Washington, DC, p 167-182

Kemp PF, Sherr BF, Sherr EB, Cole JJ (1993) Handbook of methods in aquatic microbial ecology. CRC Press, Boca Raton, FL

Kettle AJ, Andreae MO (2000) Flux of dimethylsulfide from the oceans: a comparison of updated data sets and flux models. J Geophys Res D 105:26793-26808

Kiene RP, Slezak D (2006) Low dissolved DMSP concentrations in seawater revealed by small-volume gravity filtration and dialysis sampling. Limnol Oceanogr Methods 4:80-95

Kirst G (1996) Osmotic adjustment in phytoplankton and macroalgae. In: Kiene RP, Visscher PT, Keller MD, Kirst GO (eds) Biological and environmental chemistry of DMSP and related sulfonium compounds. Plenum Press, New York, p 121-129

Kirst GO, Thiel C, Wolff H, Nothnagel J, Wanzek M, Ulmke R (1991) Dimethylsulfoniopropionate (DMSP) in ice-algae and its possible biological role. Mar Chem 35:381-388

Kogure K, Simidu U, Taga N (1979) A tentative direct microscopic method for counting living marine bacteria. Can J Microbiol 25:415-420

> Lesser MP, Farrell JH (2004) Exposure to solar radiation increases damage to both host tissues and algal symbionts of corals during thermal stress. Coral Reefs 23:367-377

Lesser MP, Shick JM (1989) Effects of irradiance and ultraviolet radiation on photoadaptation in the zooxanthellae of Aiptasia pallida: primary production, photoinhibition, and enzymic defenses against oxygen toxicity. Mar Biol 102: 243-255

Matrai PA, Keller MD (1994) Total organic sulfur and dimethylsulfoniopropionate in marine phytoplankton: intracellular variations. Mar Biol 119:61-68

> Niki T, Kunugi M, Otsuki A (2000) DMSP-lyase activity in five marine phytoplankton species: its potential importance in DMS production. Mar Biol 136:759-764

Parsons TR, Maita Y, Lalli CM (1984) Plant pigments. In: Parsons TR, Maita Y, Lalli CM (eds) A manual of chemical and biological methods for seawater analysis. Pergamon, Oxford, p 99-112

> Pawlowski J, Holzmann M, Fahrni JF, Pochon X, Lee JJ (2001) Molecular identification of algal endosymbionts in large miliolid Foraminifera. 2. Dinoflagellates. J Eukaryot Microbiol 48:368-373
Pochon X, LaJeunesse TC, Pawlowski J (2004) Biogeographic partitioning and host specialization among foraminiferan dinoflagellate symbionts (Symbiodinium; Dinophyta). Mar Biol 146:17-27

Rogers JE, Davis RH (2006) Application of a new microculturing technique to assess the effects of temperature and salinity on specific growth rates of six Symbiodinium isolates. Bull Mar Sci 79:113-126

Rowan R (2004) Thermal adaptation in reef coral symbionts. Nature 430:742

Rowan R, Powers DA (1991) A molecular genetic identification of zooxanthellae and the evolution of animal-algal symbioses. Science 251:1348-1351

- Santos SR (2004) Phylogenetic analysis of a free-living strain of Symbiodinium isolated from Jiaozhou Bay, P.R. China. J Phycol 40:395-397

Sherr EB, Sherr BF (1993) Preservation and storage of samples for enumeration of heterotrohic protisits. In: Kemp PF, Sherr BF, Sherr EB, Cole JJ (eds) Current methods in aquatic microbial ecology. Lewis Publishers, New York, p 207-212

Stefels J (2000) Physiological aspects of the production and conversion of DMSP in marine algae and higher plants. J Sea Res 43:183-197

Stefels J, Steinke M, Turner S, Malin G, Belviso S (2007) Environmental constraints on the production and removal of the climatically active gas dimethylsulphide (DMS) and implications for ecosystem modeling. Biogeochemistry 83:245-275

Steinke M, Kirst GO (1996) Enzymatic cleavage of dimethylsulfoniopropionate (DMSP) in cell-free extracts of the marine macroalga Enteromorpha clathrata (Roth) Grev. (Ulvales, Chlorophyta). J Exp Mar Biol Ecol 201:73-85

Steinke M, Daniel C, Kirst G (1996) DMSP lyase in marine macro- and microalgae. In: Kiene RP, Visscher PT, Keller MD, Kirst GO (eds) Biological and environmental chemistry of DMSP and related sulfonium compounds. Plenum Press, New York, p 317-324

Steinke M, Wolfe GV, Kirst GO (1998) Partial characterisation of dimethylsulfoniopropionate (DMSP) lyase isozymes in 6 strains of Emiliania huxleyi. Mar Ecol Prog Ser 175: $215-225$

Steinke M, Malin G, Turner SM, Liss PS (2000) Determinations of dimethylsulphoniopropionate (DMSP) lyase activity using headspace analysis of dimethylsulphide (DMS). J Sea Res 43:233-244

Steinke M, Malin G, Archer SD, Burkill PH, Liss PS (2002a) DMS production in a coccolithophorid bloom: evidence for the importance of dinoflagellate DMSP lyases. Aquat Microb Ecol 26:259-270

Steinke M, Malin G, Gibb SW, Burkill PH (2002b) Vertical and temporal variability of DMSP lyase activity in a coccolithophorid bloom in the northern North Sea. Deep-Sea Res II 49:3001-3016

Steinke M, Evans C, Lee GA, Malin G (2007) Substrate kinetics of DMSP-lyases in axenic cultures and mesocosm populations of Emiliania huxleyi. Aquat Sci 69:352-359

Sunda W, Kieber DJ, Kiene RP, Huntsman S (2002) An antioxidant function for DMSP and DMS in marine algae. Nature 418:317-320

Sunda WG, Hardison R, Kiene RP, Bucciarelli E, Harada H (2007) The effect of nitrogen limitation on cellular DMSP and DMS release in marine phytoplankton: climate feedback implications. Aquat Sci 69:341-351

Taylor BF, Gilchrist DC (1991) New routes for aerobic biodegration of dimethylsulfoniopropionate. Appl Environ Microbiol 57:3581-3584 
Trench RK (1979) The cell biology of plant-animal symbiosis. Annu Rev Plant Physiol 30:485-532

Van Alstyne KL, Houser LT (2003) Dimethylsulfide release during macroinvertebrate grazing and its role as an activated chemical defense. Mar Ecol Prog Ser 250:175-181

> Van Alstyne KL, Schupp P, Slattery M (2006) The distribution of dimethylsulfoniopropionate in tropical Pacific coral reef invertebrates. Coral Reefs 25:321-327

> van Bergeijk SA, Stal LJ (2001) Dimethylsulfoniopropionate and dimethylsulfide in the marine flatworm Convoluta roscoffensis and its algal symbiont. Mar Biol 138:209-216

Editorial responsibility: Ronald Kiene

Mobile, Alabama, USA van Diggelen J, Rozema J, Dickson DMJ, Broekman R (1986) $\beta$-3-dimethylsulphoniopropionate, proline and quaternary ammonium compounds in Spartina anglica in relation to sodium chloride, nitrogen and sulphur. New Phytol 103: 573-586

Wolfe GV, Steinke M, Kirst GO (1997) Grazing-activated chemical defense in a unicellular marine alga. Nature 387:894-897

Yoch DC (2002) Dimethylsulfoniopropionate: its sources, role in the marine food web, and biological degradation to dimethylsulfide. Appl Environ Microbiol 68:5804-5815

Submitted: July 28, 2008; Accepted: March 26, 2009

Proofs received from author(s): June 19, 2009 